\title{
The Artistic Trade and Networks of the Italian Community in London Around 1800
}

\author{
Camilla Murgia
}

In his caricature of a bas-relief found in Hadrian's Villa in Tivoli, the artist Benedetto Pastorini (1746-1807) nicely captured how his migration to Britain had impacted him, and more generally what this had meant for Italian artists (Fig. 5.1). Born in Italy in 1746, Pastorini worked with the Adam brothers in the 1760 s and early 1770 , thanks to whom he was able to build up an international professional network and consequently move to London. ${ }^{1}$ A draughtsman and engraver, Pastorini soon integrated into the Italian artistic community of the British capital and began to collaborate with the most archetypal Italian expatriate artist of this time, Francesco Bartolozzi (1727-1815). Pastorini's 1778 print epitomises his career as an integral part of a commercial network built upon the transfer of aesthetic values from one country to another. In the caption below the print, the engraver refers to the origin of the bas-relief, associating the notion of a common, Roman antiquity with the British: 'An antique bassorilevo [sic] found in Hadrian's Villa evidently of Greek Sculpture. The story seems obscure but antiquarians suppose it to represent some fact relative to antient $[\mathrm{sic}]$ britons if so, we have not entirely lost all resemblance to our ancestors.' Pastorini never returned to Italy, but kept a close relationship with his home country, as he engraved, some twenty years after this print, a series of drawings by Leonardo da Vinci belonging to the Royal Collection. ${ }^{2}$ This edition was the product of a collaboration between Italian artists based in London,

1 Robert and John Adam were Scottish architects who sojourned in Rome in the 1750s. Back in England, the two brothers established a business in London together with their other brother James. The success they encountered was considerable and much indebted to classical antiquity as discovered in Italy during their Grand Tour. On the Adam brothers, see: Joseph and Anne Rykwert, The Brothers Adam: The Men and the Style (London: Collins, 1985); Alan Andrew Tait, The Adam Brothers in Rome: Drawings from the Grand Tour (London: Scala, 2008).

2 Imitations Of Original Designs By Leonardo Da Vinci: Consisting Of Various Drawings Of Single Figures, Heads, Compositions, Horses, And Other Animals (London: John Chamberlaine, $1796-1806)$.

(C) CAMILLA MURGIA, 2019 | DOI:10.1163/9789004291997_007

This is an open access chapter distributed under the terms of the prevailing CC-BY-NC License at the time of publication. 


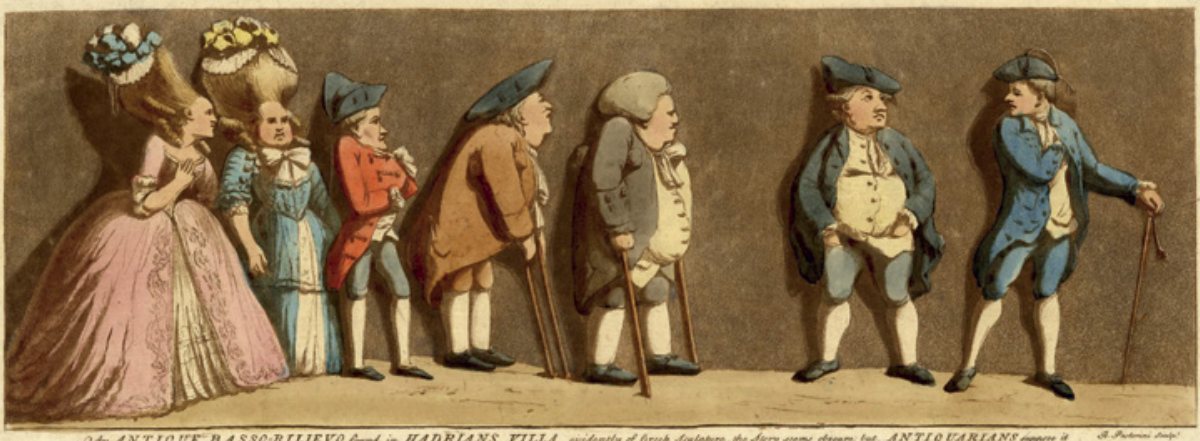

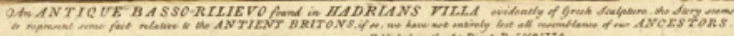

FIGURE 5.1 Benedetto Pastorini, A Caricature Comprising Figures Based on a Bas-Relief Found in Hadrian's Villa, 16 December 1778. Etching and aquatint with hand-colouring, $12.8 \times 33 \mathrm{~cm}$. London, The British Museum

(C) TRUSTEES OF THE BRITISH MUSEUM

such as Bartolozzi, and their British colleagues, such as Peltro William Tomkins (1759-1840).

Pastorini's attitude betrays a set of socio-economic, cultural and artistic practices that went far beyond the mere reproduction of works of art, which the present article proposes to investigate. The situation of Italian artists around 1800 in Britain in general and London in particular is based on the arrival of foreigners looking for a professional future abroad. It had been common for artists to gain experience abroad since the Renaissance, but on an individual basis rather than as part of a close-knit community such as the one that Italian artists established in London around 180o. Given the increased mobility of Englishmen with their Grand Tours and their interest in Italian art, the situation profoundly changed from the early eighteenth century onwards. Italian artists increasingly moved to Britain, bringing with them relationships and networks, as well as ideas and connections. This process encompasses a multitude of diverse aspects that contributes to questions of trade strategies, diffusion practices and the internationalisation of the British art market, which changed from a closed national market that only imported to a more open environment. This chapter intends to primarily investigate the background of and reasons for this development, as well as its impact, in order to reconstruct the networks that such mobility enabled. 


\section{Artistic Mobility and the Rise of the London Art Market Around 1800}

Towards the end of the eighteenth century, London was a crucial economic centre not only for the United Kingdom, but also for Europe more generally. While the French Revolution and the subsequent Napoleonic regime significantly affected France, England was experiencing prosperity. ${ }^{3}$ Foreigners on the run for the wars raging on the Continent sought out a safe place to settle and resume business, and many found their way to London. Such a political situation, therefore, resulted in an important boom of trade and commerce. ${ }^{4}$ Burton Frederickson and Julia Armstrong have demonstrated that a great majority of the paintings that left European countries, such as France and Italy, circulated at least once through England beginning around 1780. The growth of the British art trade strongly depended upon the political upheavals engendered first by the French Revolution and then the Napoleonic Wars. ${ }^{5}$ The flow of works of art from the Continent to England represented, within this context, a rapid and explicit response to the political situation.

The arrival of the Orléans collection in 1793 marked an important moment in the development of London as a trade platform for artworks. This event represented a benchmark for the history of collections because it provided the British public, which was mainly accustomed to displays of contemporary art or private collections, with the opportunity to see old master paintings of virtually unrivalled quality. ${ }^{6}$ Hence, from the 1790 os until the first decades of the nineteenth century, London offered a point of reference for the art market. The city also witnessed the rise of many collections that were assembled under different forms and with different purposes.

3 Jeremy Warren and Adriana Turpin, eds., Auctions, Agents and Dealers: The Mechanisms of the Art Market 1660-1830 (London: Archaeopress, 2007); Benedicte Miyamoto, "Making Pictures Marketable': Expertise and the Georgian Art Market," in Marketing Art in the British Isles, 1700 to the Present: A Cultural History, eds. Charlotte Gould and Sophie Mesplède (Farnham: Ashgate, 2012), 119-34.

4 On London's economic growth and its relationship to the development of the art market, see: Thomas M. Bayer and John R. Page, The Development of the Art Market in England: Money as Muse, 1730-19oo (London: Pickering \& Chatto, 2011).

5 Burton B. Frederickson, Julia I. Armstrong, and Doris A. Mendenhall, The Index of Paintings Sold in the British Isles during the Nineteenth Century, vol. 1 (Oxford: Clio, 1988), 11.

6 David Bindman, "The Orléans Collection and its Impact on British Art," in La Circulation des œeuvres d'art, 1789-1848, eds. Roberta Panzanelli and Monica Preti-Hamard (Rennes: Presses Universitaires de Rennes, 2007), 57-66; Donata Levi, "Like the Leaves of the Sybil': The Orléans Collection and the Debate on a National Gallery in Great Britain," in La Circulation des oeuvres d'art, 67-82. 
However, the internationalisation of the British art market did not solely concern flows of artworks coming from France. Imports from Italy were a significant part of the trade that had developed mainly throughout the eighteenth and the first years of the nineteenth centuries. ${ }^{7}$ British art dealers such as Michael Bryan, for instance, were a crucial step in the flow of paintings to England and in the development of art transactions across Europe. ${ }^{8}$ Bryan, who was a primary contributor to the sale of the Orléans collection and its display, regularly bought artworks outside of England to import into the country. The increasing circulation of artworks evidently triggered a need for a space to store, consume and display art. As a result, a number of commercial art galleries opened in London around 180o, standing alongside well-known, prominent auction houses such as Christie's or Sotheby's. These new businesses proposed a different, previously unseen trade practice: the selling exhibition. ${ }^{9}$ By combining display and sale, dealers not only diversified their range of activities, but they also attempted to provide a platform for art where commercial transactions could flourish together with a scholarly exchange.

Many of these galleries were founded by British men, such as John Boydell (Shakespeare Gallery) or Robert Bowyer (Bowyer's Historic Gallery). However, the London art market was not exclusively bound to British art dealers. In fact, there were a number of European professionals who had left their countries of origin to establish a business in England that contributed to its development. For instance, Noel Joseph Desenfans $\left(1745^{-1807}\right)$ had left France for London and then began to work with Francis Bourgeois (1753-1811), a British painter who became an art dealer. The emigration of French art professionals was particularly important during the last years of the eighteenth century as the Napoleonic regime persecuted many French citizens who, like Alexis Delahante (1767-1837), returned to France only after the Restoration. ${ }^{10}$

This phenomenon of immigration also concerned other countries. Napoleon's rule resulted in the rearrangement of the political and economic

7 Frederickson, Armstrong, and Mendenhall, The Index of Paintings, 13.

8 On Bryan, see: Julia Armstrong-Totten, "The Rise and Fall of a British Connoisseur: The Career of Michael Bryan (1757-1821), Picture Dealer extraordinaire," in Auctions, Agents and Dealers, 141-50.

9 On these shows, see: Richard D. Altick, The Shows of London (Cambridge: Belknap Press, 1978).

10 On Delahante's career, see: Sylvain Cordier, "Inventer et vendre le meuble historique: le goût et la carrière d'Alexis Delahante, peintre, expert et marchand de curiosités," Revue de l'Art 184, no. 2 (2014): 63-73. Delahante took particular care of renewing his stock of paintings. Indeed, before returning to Paris in 1814, he put 79 paintings on sale at Harry Phillips's auction house in London. For the sale catalogue, see: Getty Provenance Index Databases (GPID), Sale Cat Br-1197. 
structure of many European nations. For instance, subsequent to the French occupation of the Netherlands in 1795 , Dutch dealers reorganised their businesses, moving an important part of their trade to Hamburg." Some of them rapidly associated their commerce with other dealers in order to enhance their trade capacities and to reach an international public. In this way, Dutch painter and dealer Louis-Bernard Coclers (1741-1817) worked in partnership with his Paris-based colleague Alexandre-Joseph Paillet (1743-1814). Furthermore, a number of Flemish art professionals, such as art dealer Philippe Panné (fl. 1790-1818) or painter and art dealer Philippe-Joseph Tassaert (1732-1803), moved their commerce to London. ${ }^{12}$

\section{Italian Art and Dealers in Eighteenth-Century London}

A significant immigration of Italian artists and dealers to England occurred during the last decades of the eighteenth and the first of the nineteenth centuries. By 1800 an important community of expatriate artists had settled in London, introducing the production of Italian art abroad and assimilating into the British model upon their arrival in England. Many artists' careers developed around print-related activities, which flourished during these years. ${ }^{13}$ Francesco Bartolozzi played a major role in this development, as he was responsible for the increasing number of Italian artists moving to London in the second half of the eighteenth century. ${ }^{14}$

Born and mainly trained in Florence as an engraver, Bartolozzi arrived in London in 1764. In England he achieved remarkable success, contributing to the development of the technique of the stipple engraving. Easier and quicker to execute than line engraving, the stipple technique largely developed in the country in the second half of the eighteenth century and stood alongside

11 Thomas Ketelsen, “In Keeping with the Truth': The German Art Market and its Role in the Education of Connoisseurs in the Eighteenth Century," in Auctions, Agents and Dealers, $151-60$.

12 Dries Lyna, "In Search of a British Connection: Flemish Dealers on the London Art Market and the Taste for Continental Painting (1750-180o)," in Marketing Art in the British Isles, 101-17.

13 Timothy Clayton, The English Print 1688-1802 (New Haven - London: Yale University Press, 1997). See also: James Hamilton, A Strange Business: Making Art and Money in NineteenthCentury Britain (London: Atlantic Books, 2014); Miyamoto, “Making Pictures Marketable."

14 On Bartolozzi, see: Barbara Jatta, ed., Francesco Bartolozzi: incisore delle grazie (Rome: Artemide, 1995); Andrew White Tuer, Bartolozzi and his Works (London: Field \& Tuer, 1885); Selwyn Brinton, Bartolozzi and his Pupils in England (London: A. Siegle, 1903). 
successful and existing techniques, such as mezzotint. ${ }^{15}$ Bartolozzi was elected member of the Royal Academy in 1768 and was among the co-founders of the Society of Engravers. He produced prints after old masters such as Guercinoone of the artists he engraved the most-and his contemporaries Giovanni Battista Cipriani (1727-85) and Angelika Kaufmann (1741-1807). Both London residents, Kaufmann and Cipriani were respectively Swiss and Italian, and their friendship with Bartolozzi epitomises the multicultural alliances that so strongly characterised the Italian community in London at that time. Thanks to a large production of prints after old and modern masters, Bartolozzi became a reference for art and publishing markets. Furthermore, he retained strong connections with his Italian counterparts, especially those from the Venetian region, therefore establishing a crossroads between the two countries. Italian expatriate engravers nourished the dense network of art professionals gravitating towards Bartolozzi, who also generated close links with British artists and dealers.

Within the context of the internationalisation of the London art market, one primary research question arises: how did these individuals manage to position themselves as prominent art professionals in a foreign country? Italian artists developed a set of trade practices that enhanced their own national identity and allowed for a diverse, multi-layered response to the growing demand for the types of works of art that characterise the second half of the eighteenth century. Three strategies are particularly relevant and will be discussed in the following paragraphs: the perception of these individuals as linked to a singular nationally defined community; the permeability of and exchanges between art-related professions, such as printmaking and restoration, or printmaking and teaching drawing; and, finally, their strategy of operating on the crossroads of two economic and artistic realms, England and Italy.

These three business strategies and approaches to an internationalised art market are the direct result of a long history of artistic exchanges between Italy and the United Kingdom. The British interest in Italian art originated in the beginning of the "long" eighteenth century thanks to a growing attention for art. ${ }^{16}$ Grand Tourists, such as Sir William Hamilton, cultivated international connections through their travels across Europe and contributed to the development of a network of collectors, men of letters, artists and art dealers working both

\footnotetext{
15 Clayton, The English Print, 216-8; Antony Griffiths, Prints and Printmaking:An Introduction to the History and Techniques (Los Angeles: University of California Press, 1996), 77-87.

16 Iain Pears, The Discovery of Painting: The Growth of Interest in the Arts in England (16801768) (Yale: Yale University Press, 1991).
} 
in England and Italy. Iain Pears has demonstrated that from about the end of the seventeenth century onwards the interest in art grew significantly and that this process spread through social classes. ${ }^{17}$ The art market followed this interest and fed the demand for artworks. Such a context, therefore, was an ideal seedbed for Italian dealers and artists settling in England.

The increase of art market transactions inevitably questioned dealers' competences and their selling strategies and abilities, as a satirical print by Rowlandson (Fig. 5.2) illustrates. A well-dressed, fashionable Englishman and his counsellor are examining a painting by Guido Reni that an Italian art dealer attempts to sell to them. The print satirises both the credulity of the Englishman and the trading skills of the dealer. Published in 1812, this sheet shows to what extent Italian art interested British collectors, partly due to the fact that in these years the English could not visit Italy. ${ }^{18}$ Moreover, the development and internationalisation of the art market contributed to the bad reputation of art dealers. Newspapers regularly targeted art dealers and their reputation:

The profession of a picture-dealer has been so abused, that the following anecdote of George the Third, concerning their trade, need not surprise us; nor of that when his Majesty, turning to Sir William Hamilton, on his return from Naples, said, 'How is it, Sir William, that whenever I send out a gentleman to Italy, he is sure to return a picture-dealer.'19

The growth of the number of transactions of artworks that took place in London betrays the enthusiasm for art that also led to a reconfiguration of the methods by which collections were formed. Important collections, such as those of the Duke of Devonshire or of Agar-Ellis, assembled in the years 1760-9os, proved, according to Anna Jameson, that 'the purchase of pictures had by this time become a fashion.'20 Jameson criticised, however, the superficiality that characterised the description of artworks in collection catalogues. According to her, the state of things changed with the French Revolution and with the subsequent financial crisis that resulted in many masterpieces leaving France for England. The sale of the Orléans collection contributed to the rearrangement

\footnotetext{
17 Andrew Wilton and Ilaria Bignamini, eds., Grand Tour: The Lure of Italy in the Eighteenth Century (London: Tate Gallery, 1996).

18 Constance C. McPhee and Nadine M. Orenstein, eds., Infinite Jest: Caricature and Satire from Leonardo to Levine (New York: The Metropolitan Museum of Art, 2011), 133.

19 The Monthly Critical Gazette (1 October 1824): 443.

20 Anna Jameson, Companion to the Most Celebrated Private Galleries of Art in London (London: Saunders and Otley, 1844), xxvi.
} 


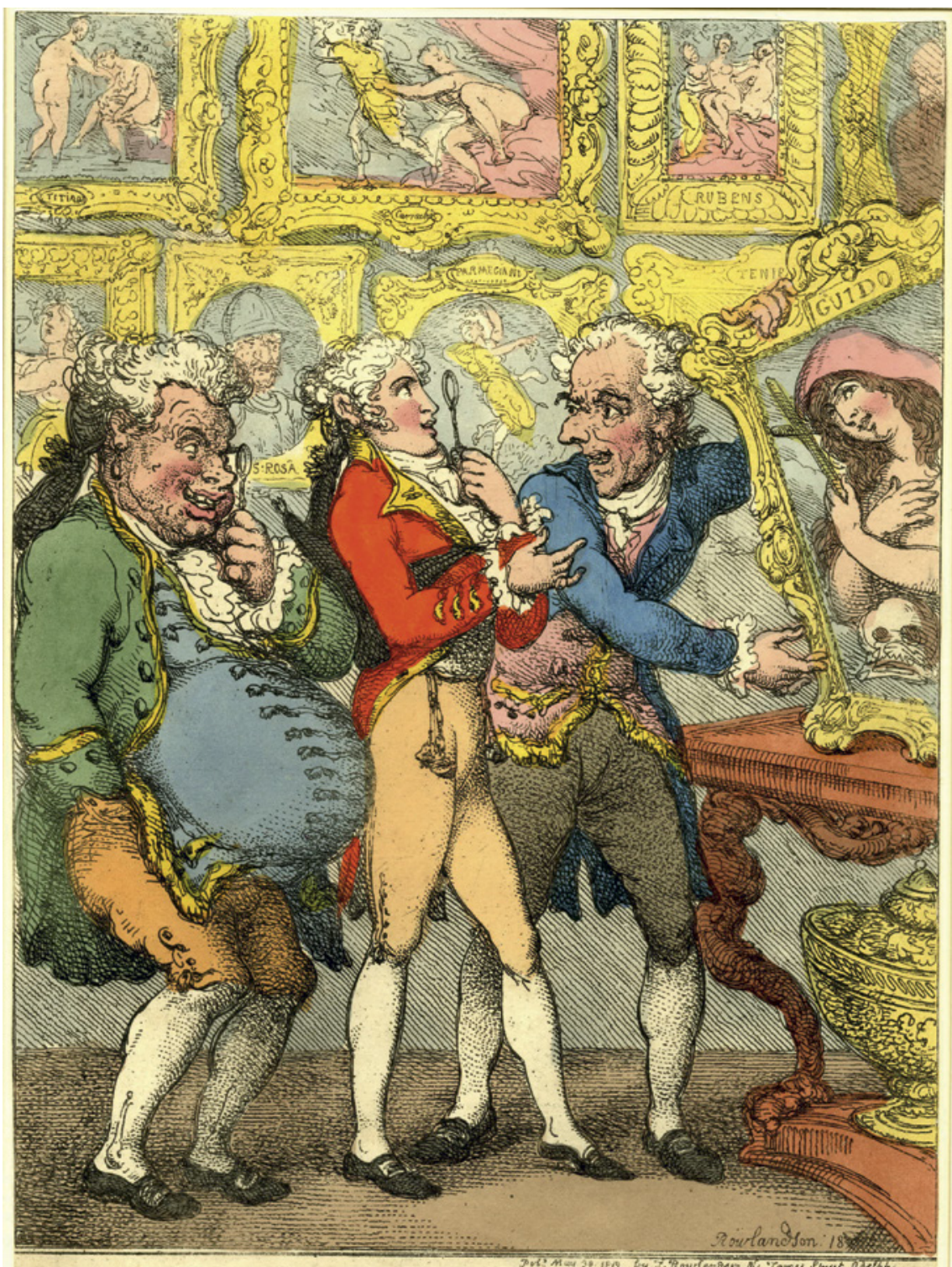

ITALitaN Pictire Dealers humbuging Mr LORd Anglaise.

FIGURE 5.2 Thomas Rowlandson, Italian Picture Dealers Humbuging My Lord Anglaise, 1812. Stipple engraving and hand-coloured etching, $31.4 \times 22.5 \mathrm{~cm}$. London, The British Museum

(C) TRUSTEES OF THE BRITISH MUSEUM 
of trade, as did subsequent collecting practices: 'Then followed the plunder of Italy, i.e., the French plundered—we [the British] purchased.21 Agents and dealers benefited from this fragile situation, and a number of commercial art galleries were created in London in the last decade of the eighteenth century. Jameson points out that of course this trend did not uniquely concern France and Italy, but rather the whole of Europe: 'One stands amazed at the number of pictures introduced by the enterprise of private dealers into England between 1795 and 1815 , during the hottest time of the war. ${ }^{22}$ Newly established businesses, such as the Gallery of the British Institution or John Wilson's European Museum, developed during these years and found considerable success. These galleries contributed not only to the increase in the trade of old masters coming from France and Italy, but also to the promotion of British art.

\section{Working as a Community}

This context also reveals the increasing demand for printed images that England experienced in the second half of the eighteenth century. Italian dealers happened to be particularly versatile and attentive to the needs of the art market as they adapted to satisfy the public's demand. To improve their impact on the British public, Italian artists and dealers often worked in partnership with their fellow countrymen or with British dealers. In the early 1790 , for instance, engraver and art dealer Mariano Bovi (1757-1813) associated with Thomas Cheesman (1760-1834) and with another Italian engraver, Michele Benedetti $\left(1745^{-1810)} .^{23}\right.$ Brothers Niccolò (1771-1813) and Luigi $\left(1765^{-1810}\right)$ Schiavonetti developed a partnership with their master, Bartolozzi. These associations were not bound to the London art market; they also concerned the rest of England. In Manchester, for example, Vittore Zanetti (c. 1746-1855) and Thomas Agnew (1794-1871) associated in $1817 .{ }^{24}$

21 Jameson, Companion, xxx. This passage was also highlighted on the occasion of the review of Jameson's book, published in 1844: "Fine Arts. Companion to the Most Celebrated Private Galleries of Art in London. By Mrs. Jameson," The Atheneum, 27 July 1844: 698-9.

22 Jameson, Companion, xxxi.

23 Ian Maxted, The London Book Trades, 1775-180o: A Preliminary Checklist of Members (Folkestone: Dawson, 1977); Id., The London Book Trades, 1735-1775: A Checklist of Members in Trade Directories and in Musgrave's 'Obituary' (Exeter: J. Maxted, 1984). See also the University of Birmingham's database on the British Book Trade Index (ввтI): http:// www.bbti.bham.ac.uk/search.htm.

24 An advertisement of 1825 mentioned them as carvers and gilders, specialised in mirrors and picture frame manufacturing. See: Manchester Central Library: GB127.Broadsides/ F1825.2. Indeed, Zanetti had apparently been running his business since about 1804, 
Partnership provided artists and dealers with the possibility to strengthen their trade capacities and to diversify their stock. The Italian community in London often relied on a figure who is considered a benchmark for the process of internationalisation of the art market around 1800: Tuscan engraver and art dealer Bartolozzi. The network that the Italian printmaker was able to establish was formative for its members, triggering a sense of belonging and serving as a reference point. Moreover, because of his success and his position as a Royal Academician, Bartolozzi was a touchpoint for the London artistic world; a number of artists and dealers were keen to parade their connection to the master. Their partnership was perceived as the work of a group of professionals and no longer as an individual initiative. For instance, Bovi, a pupil of Bartolozzi who came to London in the early 178 os thanks to the recommendation of King Ferdinand IV, followed his master and specialised in stipple engraving. Some of the prints he produced or published mentioned his professional affiliation with Bartolozzi and are inscribed, 'Engraved by M. Bovi late Pupil of F. Bartolozzi. ${ }^{25}$

The ability of Italians to integrate into their current setting significantly contributed to the community's paramount role in the diffusion of printed images. Such an integration is evident in the adaptation of Italian artists to the British context, as many of them anglicised their names-Benedetto Pastorini became 'Benedict' and Giovanni Vendramini became 'John.' But it also affected the impact that their trade tactics and image diffusion had on the British art world. Printed images developed on several levels and affected, in different ways, three main categories of art market's professionals: artists, collectors and dealers.

How is it possible that a group of individuals, working independently but creating partnerships, affected the art market in such a way that their activities were perceived as a single entity? How did they develop an international response to the growing demand for artworks that characterised the second half of the eighteenth century? In other words, did Bartolozzi create a model

when he opened a picture frame shop in Manchester, and started to sell paintings directly imported from the Continent. See: John Seed, "Commerce and Liberal Arts': The Political Economy of Art in Manchester, 1775-1860," in The Culture of Capital: Art, Power and the Nineteenth Century Middle-Class, eds. Janet Wolff and John Seed (Manchester: Manchester University Press, 1988), 52. The company had significant success and survived until 2013 when, due to financial problems, the London branch on Albemarle Street closed. Agnews's archives and stock books were recently acquired by the National Gallery of Art.

25 See for instance the prints Bovi executed after the drawing by Countess Lavinia Spencer published in 1792: London, British Museum, Department of Prints and Drawings, Acc. no. 1917,1208.3313. 
or did he follow an existing one? When the master arrived to England in the 1760 s, he relied on his relationship with a fellow Italian artist who came to England a few years earlier, Giovanni Battista Cipriani, who introduced him to the English art world and helped him to create a professional network. Even more importantly, he understood that the rising interest in printed images and the growing art market in London were deeply linked, and he rapidly developed a winning strategy: the diversification of printing techniques as an instrument to populate the market with a variety of artworks. Evidently, to achieve his goal the artist needed not only an established business, but also a number of fellow professionals who could easily reproduce the images and disperse them through art dealing. This model functioned extremely well because it represented a niche of production that was unknown in London.

In this regard, Bartolozzi's strategy seems very close to the career of another engraver, Johann Georg Wille (1715-1808). Wille moved from his native Germany to Paris in the second half of the eighteenth century and triggered the mobility of a number of his countrymen, such as Jakob Philipp Hackert (1737-1807), Johann Friedrich August Tischbein (1750-1812) and Johann Gotthard Müller (1747-1830). A member of the Académie Royale, Wille filled a gap in the Parisian art world as he produced artworks to satisfy the growing demand for printed images. ${ }^{26}$ But while Wille achieved such a project within an institutional context-his workshop operated as a part of the Académie Royale-Bartolozzi developed a set of collaborations which, originating from engraving, affected the whole of the London art market and its internationalisation. Bartolozzi's aim was similar to Wille's objective in creating a widespanning network and in ideally tempting young artists to move to London, many of whom returned home after their formative years and spread this established model elsewhere.

Partnerships linked to printmaking constituted a solid background for the development of London's art market and for the mobility of the Italian community. It was indeed during these years that Italian-born Paul Colnaghi (1751-1833) founded his business, initiating one of the most important art enterprises that England had ever known. In 1785 Colnaghi joined the print

26 Rena M. Hoisington, "Learning to Etch," in Artists and Amateurs: Etching in 18th-Century France, eds. Perrin Stein, Charlotte Guichard, and Rena M. Hoisington (New York: The Metropolitan Museum of Art, 2011), 31. On Wille and his pupils, see: Hein-Thomas Schulze Altcappenberg, 'Le Voltaire de l'art.' Johann Georg Wille (1715-1808) und seine Schule in Paris (Münster: Lit-Verlag, 1987); Élisabeth Décultot, Michel Espagne, and François-René Martin, eds., Johann Georg Wille (1715-1808) et son milieu. Un réseau européen de l'art au XVIII ${ }^{e}$ siècle (Paris: École du Louvre, 2009). 
shop of Anthony Torre after a brief sojourn in the Paris branch of Torre's shop. ${ }^{27}$ Following the boom of the demand for prints, Torre's shop grew considerably, and when he went back to Milan in 1788, Colnaghi became responsible for the art gallery. Colnaghi soon entered into a partnership with fellow Italian emigrants. First, he associated with Anthony Molteno (fl. 1784-1845), who had moved from Milan. The company, Molteno, Colnaghi \& Co., was thus created in London, while the Paris branch prospered from Torre's activities thanks to a collaboration with other Italian-born art dealers, such as Sebastiano Tessari and Joseph Zanna. ${ }^{28}$ Tessari and Zanna's businesses were established in Augsburg and Brussels, respectively. This international connection provided the company with an important European counterpart. In 1793 Molteno left the partnership to pursue his own career as an art dealer and Colnaghi solicited other Italian expatriate artists, such as Luigi Schiavonetti and Gaetano Testolini (1760-1818), to join the gallery. ${ }^{29}$

The establishment of tandem businesses played a fundamental role in the development of the art trade. Printmakers and print sellers systematically bought paintings and drawings in order to reproduce them and to sell the printed reproductions. Molteno, for instance, appears to have regularly embraced such a trade programme. ${ }^{30}$ Quite a few engravers also owned drawings by contemporary artists. In this Bartolozzi also played a primary role. Many of his pupils, such as Bovi, owned, printed and published various drawings that he had

27 Timothy Clayton, "From Fireworks to Old Masters: Colnaghi and Printselling c. 1760c. 1880," in Colnaghi: The History, ed. Jeremy Howard (London: Colnaghi, 2010), 8-9. On Colnaghi, see also: Donald Garstang, ed., Art, Commerce, Scholarship: A Window onto the Art World: Colnaghi 1760-1984 (London: Colnaghi, 1984).

28 Ibid. On Tessari and Zanna, see also: Roeland Harms, Joad Raymond, and Jeroen Salman, eds., Not Dead Things: The Dissemination of Popular Print in England and Wales, Italy and the Low Countries, 1500-1820 (Leiden: Brill, 2013), 77 and 94.

29 Clayton, "From Fireworks to Old Masters," 9.

30 In fact in January 1795 he bought Francis Wheatley's drawing representing the Girl with Watercress for $£_{3.5}$. See: GPID Sale Cat Br-A5455 (Lot 67). The auction took place at Christie's and was the sale after death of Francis Wheatley. Almost one year later, on 6 January 1796, he published the print after Wheatley's work, clearly mentioning in the lettering that the British academician was the author of both painting and drawing, Bartolozzi being the engraver. On this transaction, see also: William Roberts, F. Wheatley, R.A.: His Life and Works (London: Otto, 1910), 16. In a similar way, the Schiavonetti brothers sold in 1814 a series of paintings by British artists they had engraved a few years earlier. See: GPID Sale Cat Br-1214, lot 136 for Maria Spilsbury and 140 for Robert Kerr Porter. Among them, Maria Spilsbury's Child Found, and Happiness of the Nursery Restored and Robert Kerr Porter's Family of Tippoo Weeping over the Dead Body had been respectively reproduced in 1805 and in 1801 . For the engravings of these works, see: The British Museum, Acc. no.1850,1014.214 (for Kerr Porter) and 1872,0511.311 (for Maria Spilsbury). 


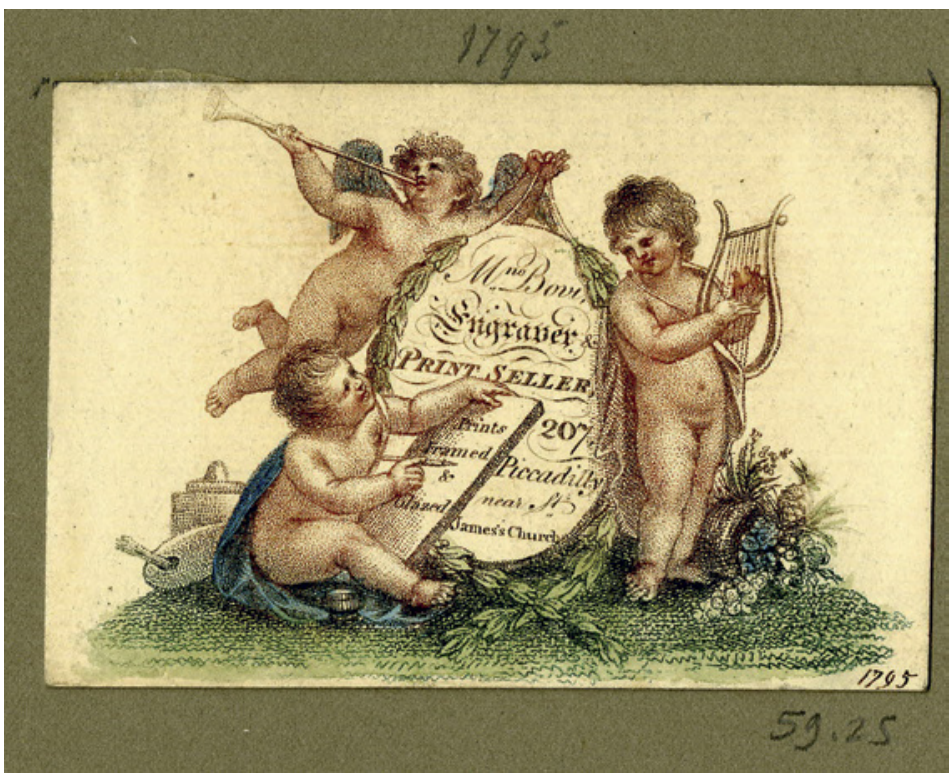

FIGURE 5.3 Anon., Draft Trade Card of Mariano Bovi, Engraver and Printseller, c. 1795. Etching and stipple with hand-colouring. London, The British Museum

(C) TRUSTEES OF THE BRITISH MUSEUM

executed, indicating this connection in the lettering of the print. ${ }^{31}$ Bovi also specialised in colour prints, following the market's demand, as a trade card dating to 1795 shows (Fig. 5.3). The card employs an artistic vocabulary that explicitly refers to Italian allegorical imagery of flying putti and infants, which Bartolozzi also regularly used. This imagery was commonly employed by other Italian printmakers and therefore came to be associated with an Italianate visual model. Bovi continued to follow the art market's trends and, while continuing to collaborate with Bartolozzi, started to produce prints on textiles for use as decoration for furniture and upholstery (Fig. 5.4). ${ }^{32}$

31 See, for instance, Bovi's Study of Three Children's Heads after a drawing by Bartolozzi. The latter's drawing belonged to Bovi's collection as the inscription on the print clearly indicated: 'The above drawing in the collection of M. Bovi' (The British Museum, Acc. no. $1868,0612.2207)$.

32 Bovi used here an imagery which directly refers to a mercantile universe: the boat on the background and the shipment on the foreground directly support the description of the activities mentioned on the card: "Engraver and print merchant." Bovi aimed at attracting clients by insisting on 'His new invented Art of Printing in Colours on Cotton, much approved of for the use of Superb Furniture.' The artist exploited the success of cotton as 


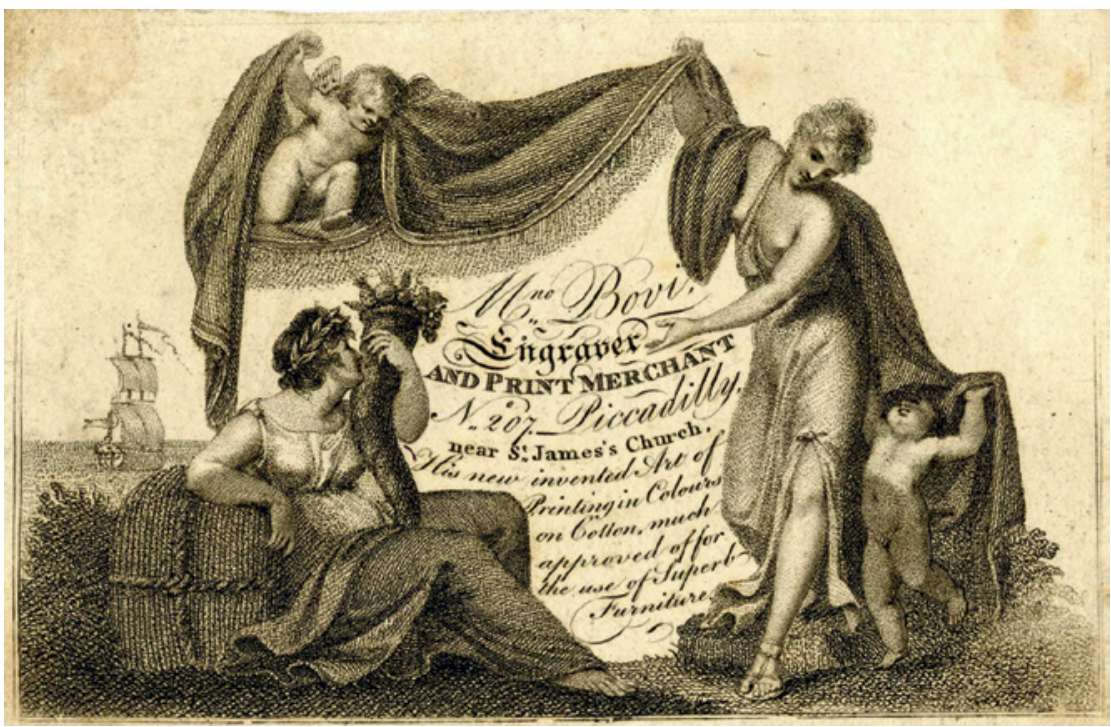

Figure 5.4 Mariano Bovi, Trade Card of Mariano Bovi, Printmaker and Publisher, 1798. Stipple engraving, $7.7 \times 11.8 \mathrm{~cm}$. London, The British Museum (C) TRUSTEES OF THE BRITISH MUSEUM

\section{Combining Professions to "Make" the Market}

The majority of the Italians who moved to London started their businesses as draughtsmen and printmakers and afterwards developed parallel activities, such as the art trade or publishing. This permeability of careers shaped the development of London's commercial activities and is not exclusively bound to Italians. Printmakers like the Boydells, Valentine Green (1739-1813) and Robert Pollard $\left(1755^{-1838}\right)$ were also printsellers and publishers. But what characterises

a printing material which developed in eighteenth-century Britain. See: Beverly Lemire, Fashion's Favourite: The Cotton Trade and the Consumer in Britain, 1660-180o (Oxford: Oxford University Press, 1991). As John Styles pointed out, the use of cotton knew a range of different applications around 1800 and the market subsequently adapted itself to such a variation. See: John Styles, "What were Cottons for in the Early Industrial Revolution," in The Spinning World: A Global History of Cotton Textiles, 1200-1850, eds. Giorgio Riello and Prasannan Parthasarathi (Oxford: Oxford University Press, 2009), 307-26. This fluctuation concerned of course the print world and Bovi therefore fundamentally contributed to this development by producing prints on cotton and on a variety of cotton-related textiles such as muslin, calico and velvet. A handwritten draft catalogue of Bovi's productions held in the British Library lists a number of prints made on several textiles: Add.Ms. 33397, ff.183-190. 
the Italian community is a diversification of their activities within an existing structure - the London art market - combined with the diffusion of an Italian visual model, such as, for instance, the flying putti and infants regularly employed by printmakers. Publishing and selling art legitimated printmakers' competences and galvanised a market where collaborations between artists became more and more frequent and essential to economic prosperity.

A trade's success depends, in such a context, on both the production and distribution of artworks. As for the production, a diversification of the artworks on offer inevitably strengthens a business's economic base and renown. In order to create variety, different versions of the same image were produced in order to satisfy multiple demands. For his Shakespeare Gallery, for instance, publisher John Boydell proposed several versions of the same image, pricing them according to the paper size and the type of impression. ${ }^{33} \mathrm{He}$ thus sold the paintings and the prints simultaneously to develop a wide-ranging stock, including expensive pictures as well as luxury and cheap reproductions, and to reach wealthy and less fortunate audiences in the same glance.

Artists like Bartolozzi, who were also print sellers and publishers, benefited from a privileged position in the art market and affected the distribution of prints. The success of this combination between printmaking and distribution was so remarkable that Italians rapidly reached foreign markets. For instance, on the occasion of the 1802 Leipzig art fair, the Monthly Magazine reported that Germans largely preferred English prints because of the array that art dealers proposed: 'Bartolozzi and Colnaghi, and other English dealers, had large assortments of English prints, aquatint, plain and coloured impressions, battle-pieces, costumes, and a variety of splendid things in the sentimental toilette-taste; which were eagerly bought by the Germans, in preference to many better productions of their own artists. ${ }^{\prime 34}$ Bartolozzi, like many other Italian engravers and dealers, was responsible for the publishing of his own artistic production. To have more time to dedicate to his artistic activity, he often collaborated with his son and pupil, Gaetano Stefano Bartolozzi (17571821). But the limits of this structure clearly surfaced when Bartolozzi had to cope with the counterfeit of one of his most successful works, the Rudiments of Drawing (Fig. 5.5). ${ }^{35}$ The work, published by Gaetano Stefano, included a set

33 Rosie Dias, Exhibiting Englishness:John Boydell's Shakespeare Gallery and the Formation of a National Aesthetic (New Haven - London: Yale University Press, 2013).

34 "Notice relative to the fine arts in Germany," The Monthly Magazine (1 January 1803): 483.

35 The success of the work was such, that another of Bartolozzi's pupils, Thomas Cheesman, published the series further and added, around 1816, new plates after Cipriani's and other masters' designs: Rudiments of Drawing the Human Figure From Cipriani, Guido, Poussin, Rubens \&c. The favourable outcome of the enterprise relied, evidently, on Bartolozzi's 


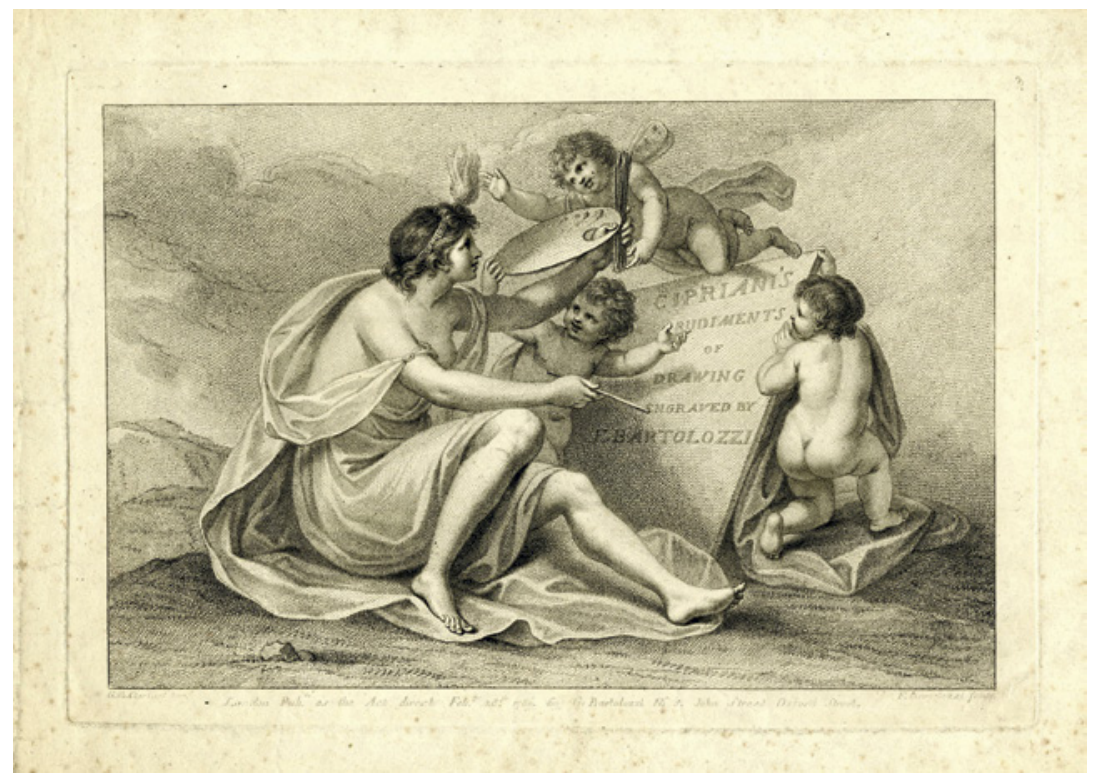

FIGURE 5.5 Francesco Bartolozzi after Giovanni Battista Cipriani, Title Page of the Rudiments of Drawing, 1786. Stipple engraving and etching, $20.8 \times 30.4 \mathrm{~cm}$. London, The British Museum

(C) TRUSTEES OF THE BRITISH MUSEUM

of prints by Bartolozzi after Cipriani's drawings featuring a number of figures, models and specimens, and was intended for use as a reference guide for those learning to draw. ${ }^{36}$ Taking advantage of the volume's success, Italian dealer and print seller Antonio Zatta (1722-1804) reproduced the same set of prints in Venice and put them on the market for the same price, a practice denounced in the 1797 exhibition catalogue of the London Royal Academy. ${ }^{37}$

legacy, as contemporaries pointed out: 'It is so well known, indeed, that Mr. Cheesman has inherited, from the late Bartolozzi, all the elegance of his master's drawing and taste in engraving, that the mere mention of his name is a sufficient pledge of excellence, and renders any eulogy unnecessary.' See: "New publications on May and June, with critical remarks," The New Monthly Magazine (1 July 1816): 532.

36 The Artist's Assistant; or School of Science; forming a Practical Introduction to the Polite Arts (Birmingham: Swinney \& Hawkins, 1801), 2. The Rudiments of Drawings paid much attention to the study of the human figure and followed, in this sense, a well diffused eighteenth-century trend. See: Peter Bicknell and Jane Munro, eds., Gilpin to Ruskin: Drawing Masters and their Manuals, 1800-1860 (Cambridge: Cambridge University Press, 1987), 16.

37 John Williams, A Critical Guide of the Present Exhibition at the Royal Academy for 1797 (London: H.D. Symonds, 1797), 19. 


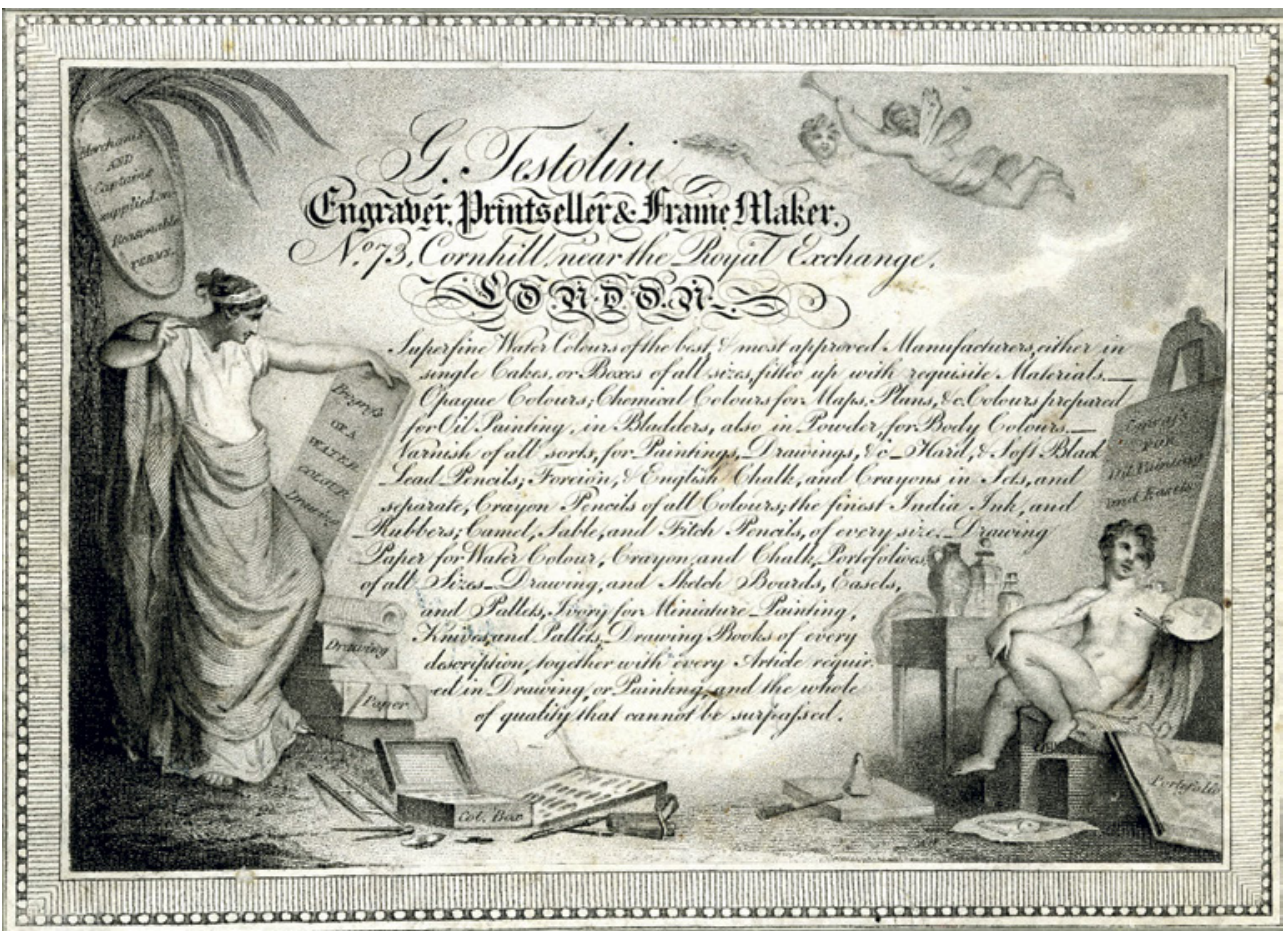

FIgure 5.6 Anon., Draft Trade Card of Gaetano Testolini, Printseller. Etching. London, The British Museum

(C) TRUSTEES OF THE BRITISH MUSEUM

In other cases, engravers and dealers proposed a variety of different supports to strengthen their business. This could include furniture design, for example, as in the case of engraver Michelangelo Pergolesi (fl. 176o-1801) who designed a set of ornaments for furniture. ${ }^{38}$ Other artists invested in the diversification of the market's offer. In such a way, Gaetano Testolini, print maker, seller and publisher, advertised on his trade card (Fig. 5.6) a series of supplies for artists, including all sorts of colours, pencils and crayons, together with prints

38 Some of these pieces are kept in the Ringling Museum of Art (Florida) and in the Metropolitan Museum in New York (Untermyer Collection). On these furniture designs, see: Stephen Donald Borys, The John and Mable Ringling Art Museum: A Guide to the Collection (Sarasota: Ringling Art Museum, 2008), 105; Yvonne Hackenbroch, Highlights of the Untermyer Collection of English and Continental Decorative Arts (New York: The Metropolitan Museum of Arts, 1977), 96 and 100. 
and framing for collectors from his shop in Cornhill, near the Royal Exchange. ${ }^{39}$ The development of artists' supplies and stationery goods appeared to be a frequent practice for printmakers whose artistic skills and knowledge legitimated the quality of the articles on sale.

A large portion of Italian professionals acting in the London art market was, directly or indirectly, linked to the printmaking world. Such a connection is not accidental, as the years around 1800 were indeed a crucial moment in the history of engraving in England. Aware of the importance of their craft, printmakers started to create instruments to protect their profession. With this in mind, the Society of Engravers was founded in 1802 to preserve printmakers' rights. It was also established in response to the fact that printmakers were not allowed to become members of the prestigious Royal Academy, founded a few decades before, unless they were also painters or sculptors. Bartolozzi, who was among the founding members of the Royal Academy, was the unique exception to this rule; he also became the first president of the Society of Engravers. As indicated in the society's regulations, the purpose of its establishment was to promote a subscription to gather funds to provide financial support in cases of sickness, retirement and widowhood. ${ }^{40}$

Italians were very well represented in the Society of Engravers because Benedetto Pastorini was among its governors. A similar situation occurred in 1807, when Giovanni Vendramini and brothers Luigi and Niccolò Schiavonetti became members of the newly founded Calcographic Society. The Calcographic Society was founded in response to the economic crisis that printmaking experienced in the first decades of the nineteenth century, mainly due to the slowdown of exportations of British prints, which had previously been much appreciated in the rest of Europe. ${ }^{41}$ The participation of Italian printmakers shows that they were actively integrated into the London printmaking sphere.

39 For the naturalisation act of Testolini, see: Parliamentary Archives, London, Private Act, 37, George III, c.1 (HL/PO/PB/1/1796/37G3n1).

40 The Universal Magazine of Knowledge and Pleasure (January-June 1804): 116-7.

41 On the Calcographic Society, see: Dongho Chun, "A Plan for Raising Money for the Calcographic Society," Print Quarterly 19, no. 4 (2002): 373-6. 


\section{On the Crossroads of Great Britain and Italy: Artistic and Commercial Exchanges}

Printmaking became increasingly professionalised all over Europe during the eighteenth century, including a growing didactic concern for the technical elements and the transmission of cultural models, in particular the Italian approach to art. With the increase in printed reproductions after old masterseither gallery paintings or frescoes and decorations in churches, palaces and villas-as well as contemporary works, this didactic concern became more visible. The basis of European high culture relied primarily on these models, which have been partly forgotten because of the predominance of French academic painting since the mid-seventeenth century. The great advantage of Italian art was, however, that it was much more regionally diverse, covered different subjects and had an overall high level of quality, at least in certain periods. In the end, this was connected to the situation in London at the end of the eighteenth century. New strategies were necessary to keep abreast of new developments. Such an approach epitomises the artists' strategy of operating on the crossroads between England and Italy. For instance, James Anthony Minasi (1776-1865), engraver and publisher, cousin of Bovi and pupil of Bartolozzi, advertised a series of drawing classes using a trade card (Fig. 5.7) whose graphic vocabulary - the winged putti-was strongly reminiscent of his master's. The depiction of infants and putti, also used by Bartolozzi and his fellow countrymen, became extremely popular in England during this period and must be ascribed to Italian artists such as Mantegna and Guercino, who regularly employed winged infants in their allegories. ${ }^{42}$ This model is only one aspect of the commercial and artistic exchange between the two countries.

Italian expatriates kept a strong connection, both artistically and commercially, with their country of origin. The rescue of a set of frescoes by Veronese illustrates, for instance, the operations taking place on the crossroads of these two countries. William Buchanan's 1828 sale reported that Vendramini, while travelling to Italy, was impressed by Veronese's frescoes at La Soranzo's Palace in the Venetian region where he was born. The frescoes were nearly consigned to demolition, but Vendramini, aware of their beauty, 'conceived the design of procuring them to enrich the Fine Arts of the country of his adoption. ${ }^{43}$ The catalogue entry on these frescoes insists on the magnanimity of the Italian engraver, thanks to whom the masterpieces were not only rescued but also ar-

42 Jane K. Brown, The Persistence of Allegory: Drama and Neoclassicism from Shakespeare to Wagner (Pennsylvania: Pennsylvania University Press, 2007), 11. 


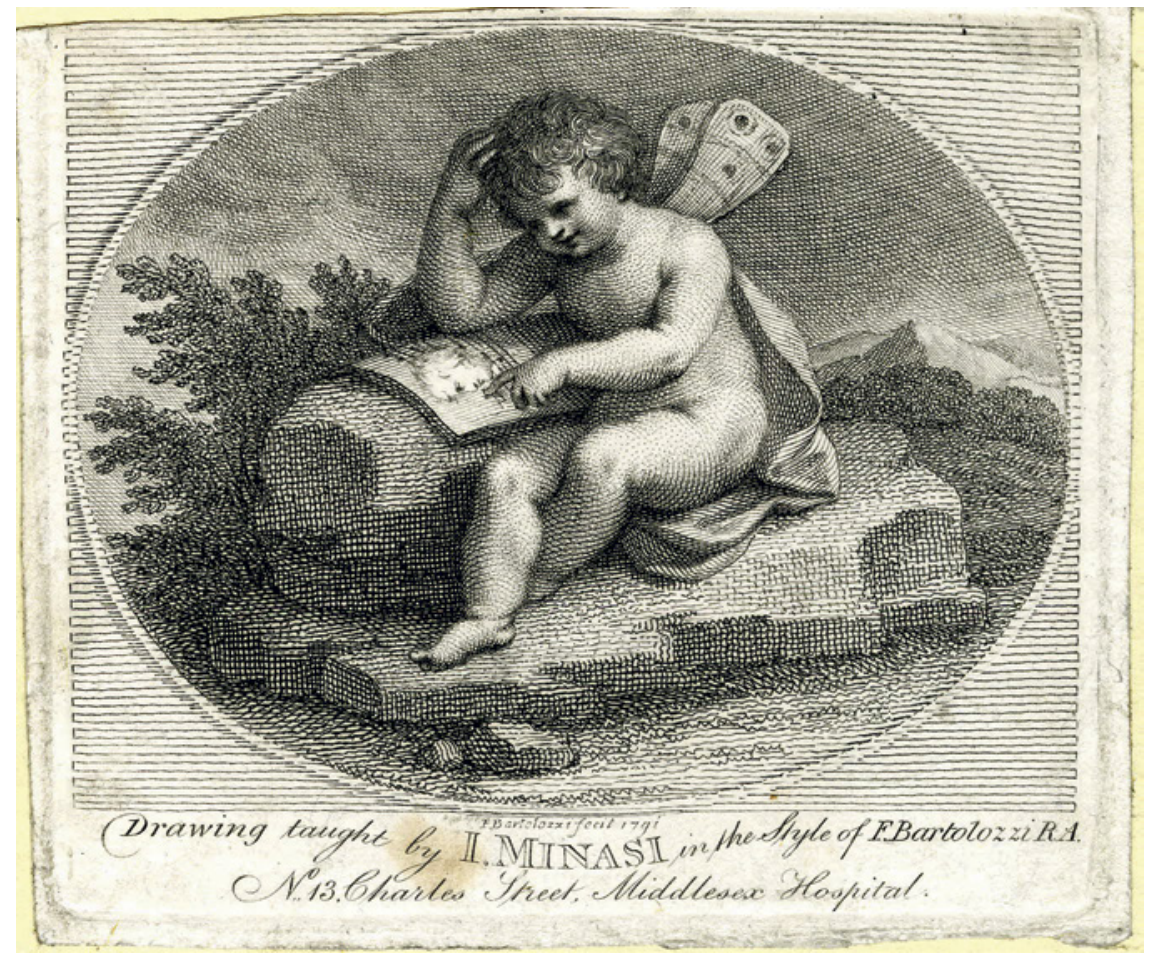

FIg URE 5.7 Francesco Bartolozzi, Draft Trade Card of James Anthony Minasi, c. 1791. Etching and engraving, 6th state. London: The British Museum (C) TRUSTEES OF THE BRITISH MUSEUM

rived in England. This account is representative of the attachment of Italian expatriates to their home country and demonstrates the growing importance of the status of printmakers in England around 1800.

Art dealer Antonio Cesare de Poggi (1744-1836) also developed his career operating between his native Italy and London. Poggi was among the few Italian artists who established a print and drawing business in London without being himself a printmaker. In fact he trained as a painter and reached England around $1768 .{ }^{44}$ He sojourned first in Devon, where he met James Northcote,

44 Zsuzsa Gonda, “Noble and Generous Actions, by Whomsoever Performed': Antonio Cesare Poggi and John Trumbull," in Ex Fumo Lucem: Baroque Studies in Honour of Klára Garas, ed. Zsuzanna Dobos, vol. 1 (Budapest: Museum of Fine Arts, 1999), 221-32. On Poggi, see also: Camilla Murgia, "Transposed Models: The British Career of Antonio Cesare de Poggi (1744-1836)," Predella 38 (2014): 173-83. 
a pupil of Sir Joshua Reynolds (1723-92).45 Thanks to Reynolds's recommendations, Poggi rapidly integrated into the British art world. The Italian artist subsequently moved to London, where he established his own business and apparently travelled regularly to Italy with his wife, Hester Lewis. Continuing his activities as an art dealer while in Italy, Poggi made use of his British relationships, as is clear from a letter written by his wife in January 1777 , while sojourning in Florence, to the couple's friend, Ozias Humphrey (1742-1810), a British portrait painter living in London. ${ }^{46}$ In London, Poggi established a successful business as a fan maker. Collectors sought after his fans based on designs by fellow artists, such as Bartolozzi. The account that the writer Fanny Burney left of a visit to his shop in 1781 is helpful to understand the fashionable character of these luxury objects, as well as their international production: 'I passed the whole day at Sir Joshua Reynolds's with Miss Palmer, who, in the morning, took me to see some most beautiful fans, painted by Poggi, from designs of Sir Joshua, Angelica, West, and Cipriani, on leather; they are, indeed more delightful than can be imagined. ${ }^{47}$ Burney's report is representative of Poggi's double strategy: the collaboration with British or Anglo-Saxon artists on the one hand and with Italian expatriate artists on the other.

On a few occasions, Italian emigrants dedicated themselves exclusively to art dealing, returning regularly to Italy to fill their stock of artworks. This was the case for Angelo Bonelli, who moved from Rome to London in the late eighteenth century and established his commercial gallery on Duke Street. ${ }^{48}$ His first sales took place in 1803 and lasted apparently until 1818.49 Bonelli mainly sold old master paintings focusing on Italian painters, such as the Carraccis, Federico Barocci or Andrea Locatelli, in addition to French masters, such as Claude Lorrain and Northern European painters, such as Paul Bril or Jan Both. The art dealer bought these items directly from their owners, without appealing to any intermediary figure. Before returning to Italy to undertake

45 Stephen Lucius Gwynn, Memorials of an Eighteenth Century Painter (James Northcote) (London: T. Fischer Unwin, 1898), 116-7.

46 Letter from Hester Poggi to Ozias Humphrey, Florence, 20 January 1777. London, The Royal Academy of Arts, HU/2/49. Poggi apparently borrowed some money from Humphrey to pay a debt and intended to send to his friend a bill for some paintings his British fellow had in custody.

47 Frances Burney, Diary and Letters of Madame d'Arblay, edited by her Niece, Charlotte Barrett, vol. 2 (London: Hurst and Blackett, 1854), 10. On Fanny Burney's visit to Poggi's shop, see also: Dorothy Moulton Mayer, Angelica Kauffmann, R.A., 1741-1807 (Gerrards Cross: Smythe, 1972), 93; Jane Roberts, Prudence Sutcliffe, and Susan Mayor, Unfolding Pictures: Fans in the Royal Collection (London: The Royal Collection, 2005), 83.

48 John Feltham, The Picture of London (London: Phillips, 1805), 261.

49 The GPID recorded a last sale in 1814. 
an acquisition campaign, Bonelli would sell all of the items in his possession at public auction. The advertisements of these events provide evidence of the economic situation and the investments that the Italian dealer undertook in moving the paintings from Italy to the United Kingdom. In May 1804, for instance, just before leaving London, Bonelli advertised an important auction that was meant to take place not in his gallery, but on Old Bond Street in the rooms of a renowned auctioneer, Charles Farebrother. ${ }^{50}$ The advertisement clearly states that Bonelli personally bought the Italian masterworks, intending them for a British audience: 'Signior [sic] Bonelli spared neither expense nor pains in selecting the chef d'œuvres, and being now on the point of returning to Rome, the whole of the Gallery will, therefore, be submitted peremptorily, and without reserve, to the protection of a discerning and liberal British public. ${ }^{51}$ The sales catalogue listed, as Frederickson points out, a series of prestigious provenances. ${ }^{52}$ Bonelli apparently hoped, in such a way, to increase his profit. Frederickson noticed, in fact, that all of the lots in this auction had already appeared in another sale, which took place at Christie's in February of the same year. ${ }^{53}$ Bonelli significantly modified the catalogue's contents to embellish the items' descriptions, which, although exaggerated, employ the marketing tactic of the inclusion of a system of visual references based on Italian art. For instance, when listing Federico Barocci's Christ Calling Andreas, Bonelli stated: 'In this picture the connoisseur will admire the superiority of colouring of that great master, who has united the design of Raphael to the colouring of Correggio.54

\section{Marketing Italian(ate) Art and the Search for a National Artistic Production}

The success of Italian engravers in London also contributed to the ongoing discussion around printmaking and Italian art collecting in general. With the arrival of Italian emigrants and the rise of Bartolozzi's pupils in the $1780 \mathrm{os}$, the number of transactions concerning Italian art grew significantly. For instance, the acquisition of several drawings by Guercino, which entered the

5o The company apparently existed since the early years of the nineteenth century. Cash books and miscellaneous documents are kept in the London Metropolitan Archives: $\mathrm{CLC} / \mathrm{B} / 08$.

51 Morning Chronicle, 2 May 1804: 3.

52 GPID Sale Cat Br-257.

53 GPID Sale Cat Br-241.

54 GPID Sale Cat Br-151-A (Lot 22). 
Royal Collection under King George III, played a major role in the development of knowledge about the Italian artist. By engraving the drawings in the Royal Collection, Bartolozzi entertained and intensified this growing interest. The data concerning Guercino's sales during the second half of the eighteenth century are representative of the importance of this period in the history of collecting and of the reception of Italian art in general. Between 1751 and 1759, only twenty-five lot numbers are recorded for Guercino in sales taking place in London. ${ }^{55}$ On the other hand, a few decades later, this number exploded with 222 lots recorded between 1780 and 1789. In 1803 Josiah Boydell was well aware that most of the British engravings had been executed by foreign artists and underlined the need for a proper training of printmakers, which would lead to a truly national "school" of printmaking:

we had in England but a small number of eminent Engravers, and most of them were foreigners. To remove this defect, it was requisite to bestow upon those, who seemed capable of improvement, a proper cultivation, together with such rewards as seemed absolutely necessary to stimulate men of genius and prompts them to proceed with resolution and spirit. ${ }^{56}$

On the other hand, Boydell's success particularly relied on Bartolozzi's work. In 1803, in fact, Boydell published a portfolio of eighty-two prints that the Florentine artist engraved after the drawings by Guercino in the Royal Collection. The success of this volume was considerable, and Boydell went on to publish a second series consisting of seventy-four prints etched by Bartolozzi after other Italian masterworks, from Michelangelo to the Carraccis, also belonging to the Royal Collection. In his catalogue Boydell insisted on the fact that Bartolozzi had executed all the prints in England, but also that the sheets show Guercino's characteristic manner:

The Prints contained in these Two Volumes are the first productions of Mr. Bartolozzi on his coming into this Country, and are universally esteemed by connoisseurs to be in the best style of this celebrated Artist; they have also the peculiar merit of possessing all the spirit and character of the exquisite Works of Guercino, \&c. after which they were engraved. ${ }^{57}$

55 Analysis based on the sales recorded in the GPID.

56 An Alphabetical Catalogue of Plates, engraved by the most esteemed artists, after the finest pictures and drawings of the Italian, Flemish, German, French, English, and other schools, which compose the stock of John and Josiah Boydell, engravers and printsellers (London: Boydell, 1803), xvi.

Id., xi. 
The attention paid to an artist's training represented a crucial step not only for British printmaking, but also for the constitution of collections in general. Indeed, a discussion started to develop around the need for collecting prints both as objects of aesthetic value and as material for knowledge. Around 1806, John Landseer's lecture series on engraving brought this discussion to light in his questioning of the role of the "copyist," a title ascribed to many printmakers who sold printed reproductions after paintings. ${ }^{58}$ In 1828 art dealer Thomas Wilson wrote an introductory essay in the sales catalogue of his print collection, in which he pointed out that prints were collected in England for their usefulness as illustrations rather than as artworks and proof of an artist's skill. However, according to the dealer, these works were extremely precious because they offered, through a graphic translation, the manner of an artist. ${ }^{59}$

However, new difficulties also arose in England with the changing political situation in Europe in the aftermath of the French Revolution and the reorganisation of the various countries and cultural life. The art market in general and the print market in particular suffered from this situation. Entire collections were dispersed, and new collections of prints became increasingly rare. Engravers thus entered into a more competitive situation, not limited to Britain, but also on the Continent. It is therefore no surprise that Italian expatriate art professionals, as well as their fellow British colleagues, struggled to keep their trades safe. Boydell's Shakespeare Gallery closed in 1803 following its bankruptcy; the sale of the remaining paintings took place in $1805 .{ }^{60}$ This outcome was common and concerned many Italians. In a similar way, Bovi's trade activities started to decline and, after a sale in 1802 that led to catastrophic results, the artist announced his own bankruptcy in $1804 .{ }^{61}$ Testolini's shop

$5^{8}$ John Landseer, Lectures of the Art of Engraving (London: Longman, Hurst, Rees and Orme, 1807). On Landseer's lectures and criticism of commercial printmaking, see: John Klancher, Transfiguring the Arts and Sciences: Knowledge and Cultural Institutions in the Romantic Age (Cambridge: Cambridge University Press, 2013), 75-7.

59 A catalogue raisonné of the Select Collection of Engravings of an Amateur (London: s.n., 1828), I. A year before, collector George Cumberland insisted on the didactical goal of print collecting. Cumberland, who was also an amateur printmaker and painter, defended the role of print collecting as a catalyst for knowledge: " $t$ is not to steal the ideas of the old master that we study them, but rather to amalgamate them with those of each other and our own: new ideas of beauty and grandeur can alone arise from happy combinations, and as he that has read attentively the best authors is likely to acquire the best style; so he that is conversant with the works of all the good Artists, it is most likely, will be successful in his own.' See: George Cumberland, An Essay on the Utility of Collecting the Best Works of the Ancient Engravers of the Italian School (London: W. Nicol, 1827), 15-6.

6o The 1805 sale took place at Christie's on 17-20 May: GPID Sale Cat Br-334.

61 For the 1802 sale, see: GPID Sale Cat $\mathrm{Br}-146$. For the announcement of the bankruptcy, see: London Gazette, 1 January 1804: 217 and 245. 
also ended due to financial problems and to a subsequent bankruptcy in $1808 .{ }^{62}$ Some other artists managed to move elsewhere, giving new life to their trades. Within this context, Bartolozzi's move to Lisbon in 1802 represents a key moment for the commercial activities of Italian artists in London, as many of his fellow engravers were obliged to relocate or close their businesses. Some of them, such as Domenico Pellegrini, followed Bartolozzi to Portugal and later returned to Italy. Others, such as Poggi, moved their businesses independently from Bartolozzi and attempted to start anew in Paris. Although the majority of Italian expatriate artists left England, some also managed to stay in London. For instance, Anthony Molteno not only kept his business prosperous until his death in 1816, but he also left his print shop to his son, James Anthony, who remained active until the 1830 s. $^{63}$

\section{Conclusion}

The immigration of Italian artists to London triggered a series of repercussions concerning the artistic sphere of the city, which also touched upon commercial and cultural contexts. The dense network of the production of artworks developed in a delicate period for printmaking and for British art in general. The combination of skills and the permeability of professions related to printmaking corresponded to a boom in printed images and an important growth in the art market. Prints were works of art in their own right, but in many cases they also allowed for the reproduction of paintings that were often inaccessible to clients or interested amateurs. Prints were used as substitutes for paintings, creating a demand and therefore establishing their own market. They contributed to making Italian models available and to increasing interest in different visual references. Both Italian and British prints contributed to the diffusion of British material culture until the Regency period. Because an important part of this artistic production was executed by foreigners, such as Italian immigrants, the impact these artworks had on collecting and on the knowledge associated with these works evidently had to be rearranged and positioned between national and international spheres.

62 The National Register, 25 September 1808: 616.

63 For the sale after death of Molteno, see: GPID Sale Cat Br-1534. 


\section{References}

A catalogue raisonné of the Select Collection of Engravings of an Amateur. London: s.n., 1828.

Altick, Richard D. The Shows of London. Cambridge: Belknap Press, 1978.

An Alphabetical Catalogue of Plates, engraved by the most esteemed artists, after the finest pictures and drawings of the Italian, Flemish, German, French, English, and other schools, which compose the stock of John and Josiah Boydell, engravers and printsellers. London: Boydell, 1803.

Anon. "Notice relative to the fine arts in Germany." The Monthly Magazine (1 January 1803): 483-5.

Anon. "New publications on May and June, with critical remarks." The New Monthly Magazine (1 July 1816): 532.

Anon. "An Account of all the Pictures Exhibited in the Rooms of the British Institution, from 1813 to 1823 , belonging to the Nobility and Gentry of England: with Remarks, Critical and Explanatory." The Monthly Critical Gazette (1 October 1824): 441-4.

Anon. The Universal Magazine of Knowledge and Pleasure (January-June 1804): 116-7.

Anon. London Gazette, 1 January 1804: 217 and 245.

Anon. Morning Chronicle, 2 May 1804: 3.

Anon. "Fine Arts. Companion to the most Celebrated Private Galleries of Art in London. By Mrs. Jameson." The Atheneum no. 874 (27 July 1844): 698-9.

Armstrong-Totten, Julia. "The Rise and Fall of a British Connoisseur: The Career of Michael Bryan (1757-1821), Picture Dealer extraordinaire." In Auctions, Agents and Dealers: The Mechanisms of the Art Market 1660-1830, edited by Jeremy Warren and Adriana Turpin, 141-50. London: Archaeopress, 2007.

Bayer, Thomas M., and John R. Page. The Development of the Art Market in England: Money as Muse, 1730-190o. London: Pickering \& Chatto, 2011.

Bicknell, Peter, and Jane Munro, eds. Gilpin to Ruskin. Drawing Masters and their Manuals, 180o-186o. Cambridge: Cambridge University Press, 1987.

Bindman, David. "The Orléans Collection and its Impact on British Art." In La Circulation des oeuvres d'art, 1789-1848, edited by Roberta Panzanelli and Monica Preti-Hamard, 57-66. Rennes: Presses Universitaires de Rennes, 2007.

Borys, Stephen Donald. The John and Mable Ringling Art Museum: A Guide to the Collection. Sarasota: Ringling Art Museum, 2008.

Brinton, Selwyn. Bartolozzi and his Pupils in England. London: A. Siegle, 1903.

Brown, Jane K. The Persistence of Allegory: Drama and Neoclassicism from Shakespeare to Wagner. Pennsylvania: Pennsylvania University Press, 2007.

Burney, Frances. Diary and Letters of Madame d'Arblay, edited by her Niece, Charlotte Barrett. London: Hurst and Blackett, 1854. 
Chamberlaine, John, ed. Imitations Of Original Designs By Leonardo Da Vinci: Consisting Of Various Drawings Of Single Figures, Heads, Compositions, Horses, And Other Animals. London: W. Bulmer and Co., 1796-1806.

Chun, Dongho. "A Plan for Raising Money for the Calcographic Society." Print Quarterly 19, no. 4 (2002): 373-6.

Clayton, Timothy. The English Print 1688-1802. New Haven - London: Yale University Press, 1997.

Clayton, Timothy. "From Fireworks to Old Masters: Colnaghi and Printselling c. 1760c. 1880." In Colnaghi: The History, edited by Jeremy Howard, 8-9. London: Colnaghi, 2010.

Cordier, Sylvain. "Inventer et vendre le meuble historique: le goût et la carrière d'Alexis Delahante, peintre, expert et marchand de curiosités." Revue de l'Art 184, no. 2 (2014): 63-73.

Cumberland, George. An Essay on the Utility of Collecting the Best Works of the Ancient Engravers of the Italian School. London: W. Nicol, 1827.

Décultot, Élisabeth, Michel Espagne, and François-René Martin, eds. Johann Georg Wille (1715-1808) et son milieu. Un réseau européen de l'art au XVIII e siècle. Paris: École du Louvre, 2009.

Dias, Rosie. Exhibiting Englishness:John Boydell's Shakespeare Gallery and the Formation of a National Aesthetic. New Haven - London: Yale University Press, 2013.

Feltham, John. The Picture of London. London: Phillips, 1805.

Frederickson, Burton B., Julia I. Armstrong, and Doris A. Mendenhall. The Index of Paintings Sold in the British Isles during the Nineteenth Century. Oxford: Clio, 1988.

Garstang, Donald, ed. Art, Commerce, Scholarship: A Window onto the Art World: Colnaghi 1760-1984. London: Colnaghi, 1984.

Gonda, Zsuzsa. "Noble and Generous Actions, by Whomsoever Performed': Antonio Cesare Poggi and John Trumbull." In Ex Fumo Lucem: Baroque Studies in Honour of Klára Garas, edited by Zsuzanna Dobos, vol. 1, 221-32. Budapest: Museum of Fine Arts, 1999.

Gould, Charlotte, and Sophie Mesplède, eds. Marketing Art in the British Isles, 1700 to the Present: A Cultural History. Farnham: Ashgate, 2012.

Griffiths, Antony. Prints and Printmaking: An Introduction to the History and Techniques. Los Angeles: University of California Press, 1996.

Gwynn, Stephen Lucius. Memorials of an Eighteenth Century Painter (James Northcote). London: T. Fischer Unwin, 1898.

Hackenbroch, Yvonne. Highlights of the Untermyer Collection of English and Continental Decorative Arts. New York: The Metropolitan Museum of Arts, 1977.

Hamilton, James. A Strange Business: Making Art and Money in Nineteenth-Century Britain. London: Atlantic Books, 2014. 
Harms, Roeland, Joad Raymond, and Jeroen Salman, eds. Not Dead Things: The Dissemination of Popular Print in England and Wales, Italy and the Low Countries, 1500-1820. Leiden: Brill, 2013.

Hoisington, Rena M. "Learning to Etch." In Artists and Amateurs: Etching in 18thCentury France, edited by Perrin Stein, Charlotte Guichard, and Rena M. Hoisington, 15-39. New York: The Metropolitan Museum of Art, 2011.

Imitations Of Original Designs By Leonardo Da Vinci: Consisting Of Various Drawings Of Single Figures, Heads, Compositions, Horses, And Other Animals. London: John Chamberlaine, 1796-1806.

Jameson, Anna. Companion to the Most Celebrated Private Galleries of Art in London. London: Saunders and Otley, 1844.

Jatta, Barbara, ed. Francesco Bartolozzi: incisore delle grazie. Rome: Artemide, 1995.

Ketelsen, Thomas. "In Keeping with the Truth.' The German Art Market and its Role in the Education of Connoisseurs in the Eighteenth Century." In Auctions, Agents and Dealers: The Mechanisms of the Art Market 1660-1830, edited by Jeremy Warren and Adriana Turpin, 151-60. London: Archaeopress, 2007.

Klancher, John. Transfiguring the Arts and Sciences: Knowledge and Cultural Institutions in the Romantic Age. Cambridge: Cambridge University Press, 2013.

Landseer, John. Lectures of the Art of Engraving. London: Longman, Hurst, Rees and Orme, 1807.

Lemire, Beverly. Fashion's Favourite: The Cotton Trade and the Consumer in Britain, 1660-180o. Oxford: Oxford University Press, 1991.

Levi, Donata. "Like the Leaves of the Sybil': The Orléans Collection and the Debate on a National Gallery in Great Britain." In La Circulation des æeuvres d'art, 1789-1848, edited by Roberta Panzanelli and Monica Preti-Hamard, 67-82. Rennes: Presses Universitaires de Rennes, 2007.

Lyna, Dries. "In Search of a British Connection: Flemish Dealers on the London Art Market and the Taste for Continental Painting (1750-1800)." In Marketing Art in the British Isles, 1700 to the Present: A Cultural History, edited by Charlotte Gould and Sophie Mesplède, 101-17. Farnham: Ashgate, 2012.

Maxted, Ian. The London Book Trades, 1775-1800: A Preliminary Checklist of Members. Folkestone: Dawson, 1977.

Maxted, Ian. The London Book Trades, 1735-1775: A Checklist of Members in Trade Directories and in Musgrave's 'Obituary'. Exeter: J. Maxted, 1984.

McPhee, Constance C., and Nadine M. Orenstein, eds. Infinite Jest: Caricature and Satire from Leonardo to Levine. New York: The Metropolitan Museum of Art, 2011.

Miyamoto, Bénédicte. “Making Pictures Marketable': Expertise and the Georgian Art Market." In Marketing Art in the British Isles, 1700 to the Present: A Cultural History, edited by Charlotte Gould and Sophie Mesplède, 119-34. Farnham: Ashgate, 2012. 
Moulton Mayer, Dorothy. Angelica Kauffmann, R.A., 1741-1807. Gerrards Cross: Smythe, 1972.

Murgia, Camilla. “Transposed Models: The British Career of Antonio Cesare de Poggi (1744-1836)." Predella 38 (2014): 173-83.

Pears, Iain. The Discovery of Painting: The Growth of Interest in the Arts in England (1680-1768). Yale: Yale University Press, 1991.

Roberts, Jane, Prudence Sutcliffe, and Susan Mayor. Unfolding Pictures: Fans in the Royal Collection. London: The Royal Collection, 2005.

Roberts, William. F. Wheatley, R.A.: His Life and Works. London: Otto, 1910.

Rykwert, Joseph, and Anne Rykwert. The Brothers Adam: The Men and the Style. London: Collins, 1985 .

Schulze Altcappenberg, Hein-Thomas. 'Le Voltaire de l'art.' Johann Georg Wille (17151808) und seine Schule in Paris. Münster: Lit-Verlag, 1987.

Seed, John. "'Commerce and Liberal Arts': The Political Economy of Art in Manchester, 1775-186o." In The Culture of Capital: Art, Power and the Nineteenth Century MiddleClass, edited by Janet Wolff and John Seed, 45-81. Manchester: Manchester University Press, 1988.

Styles, John. "What were Cottons for in the Early Industrial Revolution." In The Spinning World: A Global History of Cotton Textiles, 1200-1850, edited by Giorgio Riello and Prasannan Parthasarathi, 307-26. Oxford: Oxford University Press, 2009.

Tait, Alan Andrew. The Adam Brothers in Rome: Drawings from the Grand Tour. London: Scala, 2008.

The Artist's Assistant; or School of Science; forming a Practical Introduction to the Polite Arts. Birmingham: Swinney \& Hawkins, 1801.

Warren, Jeremy, and Adriana Turpin, eds. Auctions, Agents and Dealers: The Mechanisms of the Art Market 1660-1830. London: Archaeopress, 2007.

White Tuer, Andrew. Bartolozzi and his Works. London: Field \& Tuer, 1885.

Williams, John. A Critical Guide of the Present Exhibition at the Royal Academy for 1797. London: H.D. Symonds, 1797.

Wilton, Andrew, and Ilaria Bignamini, eds. Grand Tour: The Lure of Italy in the Eighteenth Century. London: Tate Gallery, 1996. 